\title{
Research on the Problems and Development of Small and Medium Enterprises in the Pearl River Delta
}

\author{
Liang Huang ${ }^{1, \mathrm{a}}$, Haowei $\mathrm{Ti}^{1, \mathrm{a}}$, Leigang Pei ${ }^{1, \mathrm{a}}$, Ding $\mathrm{Ma}^{2, \mathrm{~b}}$ \\ ${ }^{1}$ Hong Kong Asia Business College Headquarter Office, Hong Kong \\ ${ }^{2}$ Limkokwing University of Creative Technology China Office Zhengzhou, China
}

\begin{abstract}
Since the reform and opening up, the economy of the Pearl River Delta has achieved rapid development and remarkable results. Small and medium-sized enterprises in the region have also achieved rapid development in terms of quantity and quality, and have become an important part of the region. However, with economic globalization, because of continuous changes in the external environment, and its own industrial upgrading and structural adjustment, even if small and medium-sized enterprises in the Pearl River Delta region have advantages compared with other regions in China. However, there are still problems in the development process. The article mainly analyzes the financing difficulties of SMEs in the Pearl River Delta region and the brain drain in recent years, and gives corresponding countermeasures. Since small and medium-sized enterprises occupy an important position in the economy of the Pearl River Delta region, they can not only promote technological innovation and boost domestic demand for production, but also drive the employment rate to rise. Therefore, the development of small and medium-sized enterprises in the region has played a positive role in the economic progress of the Pearl River Delta region, and the place has also promoted economic development.
\end{abstract}

\section{INTRODUCTION}

For most SMEs, it is not easy to obtain loans provided by financial institutions. First, these organization have higher requirements for high-quality collateral. Secondly, SMEs are not competitive in the quantity and quality of collateral required by financial institutions due to their own scale limitations and strength. What's more, the real interest rate of SMEs in the loan process is much higher than the benchmark interest rate. Data from the Guangdong Provincial Government in 2017 showed that the actual loan interest rate provided by financial institutions to SMEs was $18.4 \%$ higher than the benchmark interest rate on average.

The financing channels are mainly divided into internal financing and external financing. External financing has an incomparable advantage over internal financing. Since external financing is mainly commercial bank loans, which is not only more stable, but also cheaper than private loans. However, commercial banks have relatively high credit requirements for corporate loans, which makes it difficult for most SMEs to meet this type of loan. The endogenous financing preferred by most SMEs refers to the use of internal funds to maintain the operation of the enterprise. The amount of money raised in this way is limited, and in most cases cannot meet the conditions for most SMEs to expand their production scales.

Due to the limitations of their own scale and strength, in order to achieve the purpose of saving costs, some small and medium-sized enterprises lack professional finance, so there will be irregular financial statements. Data shows that about $60 \%$ of SMEs cannot provide long-term standardized financial statements. Moreover, these companies will use inconsistent accounts to reduce taxes or reduce costs, which reduces the cost of SMEs. But as a result, the trust between banks and enterprises has declined, reducing the willingness of financial institutions to lend.

The business model and the form of private operation are the main characteristics of SMEs in the Pearl River Delta. However, most of the private companies are small in scale and not standardized. Moreover, many enterprises are developed from small family workshops, and the quality and capabilities of managers is not high.

\section{THE CURRENT SITUATION AND PROBLEMS OF BRAIN DRAIN IN SMALL AND MEDIUM-SIZED ENTERPRISES IN THE PEARL RIVER DELTA}

\subsection{The not perfect enterprise management system and unreasonable structure}




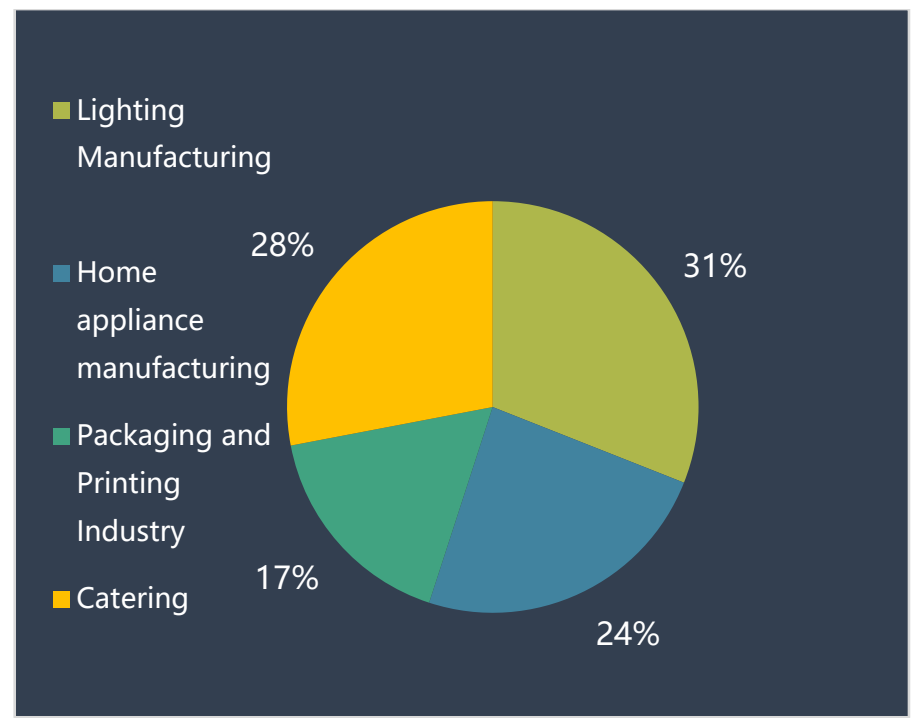

Figure 1 Turnover rate in different industries in Guangdong province

The survey results showed that in 2014 , nearly $60 \%$ of private enterprises in the Pearl River Delta faced severe job shortages. As can be seen from the above figure, different industries generally face rigorous personnel turnover problems.

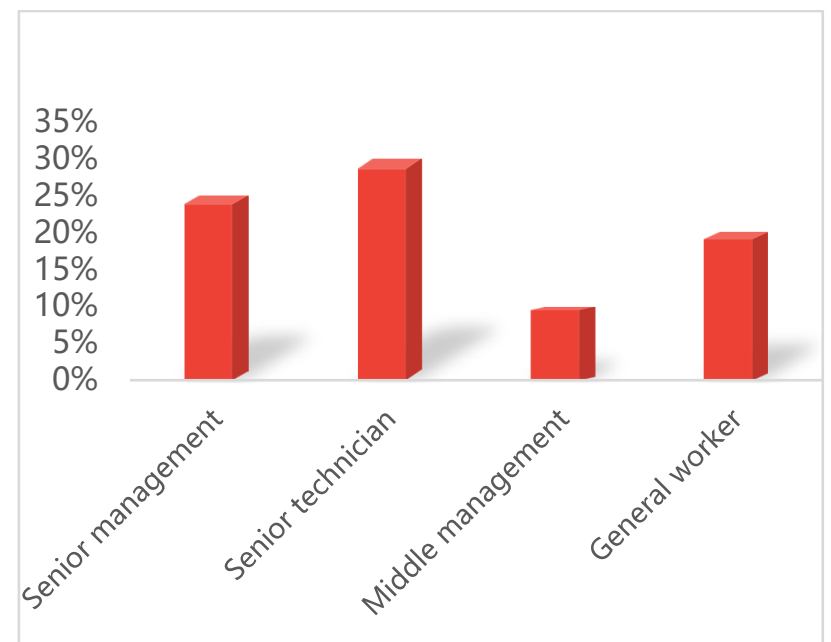

Figure 2 The turnover rate of small and medium-sized enterprises in Guangdong province

Figure 2 is mainly a statistical chart drawn from the data officially released by the Guangdong Provincial Department of Labor and Social Security. As we can see that the turnover rate of senior managers and senior technical personnel of SMEs in Guangdong Province is as high as $20 \%$ to $30 \%$, and the turnover rate of middle and grassroots managers and technical personnel is $10 \%$ to $20 \%$. The normal turnover of $8 \%$ is reasonable, which obviously shows that the turnover rate of Chinese private enterprises is abnormally high.

\subsection{The lack of advanced corporate culture atmosphere}

The value of corporate culture refers to the interpersonal communication paradigm and system formed by the employees in the long-term interaction process, and it must be linked to the business performance of the company to help the growth of the company. Many small and medium-sized enterprises in the Pearl River Delta region do not pay attention to the construction of their own corporate culture, and they lack the "people-oriented" corporate temperament. This situation can lead to insufficient corporate cohesion and employee centripetal force, and a weak sense of belonging to the company. In the internal management of some SMEs, managers are too individualistic, while the professional opinions of SME professionals are not taken seriously.

Restricted by the family-style management model, many small and medium-sized enterprises in the Pearl River Delta region hire and promote employees based on their blood relationship, resulting in mismatches in talents, positions and salaries. This kind of unfair competition makes it difficult to form an atmosphere of respect for knowledge and talents in the development of enterprises. In terms of management mode, the distrust, unauthorization or insufficient authorization of enterprise managers and subordinates makes key talents play the role of executor, which is not conducive to the cultivation of enterprise groups. As a result, there is no open and fair competition mode within the enterprise.

With the development of the country's political economy, the country has the ability to give priority planning and assistance to the regional development. Especially in recent years, with the development of the western region and the construction of a new countryside, job seekers have a wider range of employment options. They are more willing to choose cities and regions in the Pearl River Delta where wages, benefits and living costs are more advantageous. At the same time, the imperfection of the public service functions of local governments hinders job seekers to a certain extent. 


\section{SUGGESTIONS ON THE DEVELOPMENT OF SMALL AND MEDIUM ENTERPRISES IN THE PeARl River Delta REgion}

It is necessary to improve the human resource management system of the enterprise, attach importance to the professionalization and systematic training of employees. Incentives can be used to keep employees' hearts. Enterprises must learn to care for employees, and treat them as an indispensable member of the company, not just a resource that can come and go at will.

At the same time, the company should establish a stable long-term development strategy suitable for the company, and coordinate the corporate salary management, performance management and talent management. What's more, professional recruitment enterprises carry out extensive cooperation to establish their own recruitment channels and achieve diversified recruitment channels.

\subsection{Proposals for small and medium enterprises financing}

The government should improve the supply chain financial system, strengthen relevant regulations, guidance and supervision under the jurisdiction of the government, form a complete financial policy system for the development of small and medium-sized enterprises. Only sound laws on SMEs can guarantee the direct flow of funds to these companies and promote the healthy development of supply chain finance. At the same time, according to management needs, the way of establishing a credit rating system and standards for small and medium-sized enterprises in the Pearl River Delta region as well as a credit model and database can provide references for the construction of China's social credit collection system and credit intermediary institutions, and effectively collect and evaluate information.

\subsection{Increasing attractiveness of small and medium enterprises}

- Most SMEs in the Pearl River Delta region have a single business model and single products. However, since the decision-making power of most SMEs is in the hands of a core person, operators can make correct judgments and decisions on market changes in a timely manner, and find gaps in supply chain finance. Core managers can focus on areas neglected by large companies, improve their competitiveness, and gain a firm foothold in the market. Therefore, SMEs can use their various advantages to increase their visibility and credibility with high-quality products, thereby attracting the attention of supply chain financial service providers such as banks.

- The development of financial institutions in a market economy is full of opportunities and challenges. In recent years, the government has played a decisive role in the market through the process of macro-control, and has continuously improved the financial system. The multiple links involved in supply chain financial financing require perfect early warning of risks in the financing process. Therefore, the financial institution supervision department should analyze the risk characteristics, credit technology and core value of the supply chain on specific issues, and make a correct assessment.

- The local government of the Pearl River Delta should improve its service functions, create a good employment environment and social environment, and increase the attraction of the region to foreign job seekers. The government will step up labor supervision and maintain the social employment environment. A sound social security system, medical security for foreign personnel, pension and other security systems can guarantee their lives. Good employment service and talent market, as well as perfect employment platform, can solve the problem of employment and talent shortage in enterprises.

- The 21 st century is the century of talents. At present, the fiercest competition among enterprises is the competition of talents. Talents play an increasingly important role in an enterprise and are the soul engineers of an enterprise.Only by vigorously developing the establishment of a management system for the introduction and training of talents can enterprises achieve long-term sustainable development.A perfect talent reserve system is a key factor in the long-term development and success of an enterprise. For my country's current small and medium-sized enterprises, it is necessary to vigorously build a talent reserve management system in line with the enterprise, and pay attention to the all-round and comprehensive training of recruited personnel.At the same time, the human resources management department should formulate a practical, reasonable, scientific and feasible talent introduction system. Not only must we not judge heroes based on academic qualifications, but also more in line with the actual work ability and work attitude of talents. Only in this way can the company be invincible in the fierce competition.

- After the introduction of talents, the management department has made a corresponding detailed and thorough training plan for the talents, so that every new employee can become familiar with the working environment and their work content as soon as possible.During the internship period, the most suitable job position is arranged according to the specific performance of each employee according to his own situation. At the same time, the company strictly prohibits the use of nepotism to enter the company's work. In a fair and transparent management environment, every 
employee will become the backbone of the company. The company adopts long-term quality training combined with short-term job training to effectively combine practice and experience, so that every employee can make a clear position for himself during the internship and bring the greatest benefits to the company.

\section{Conclusion}

According to the survey statistics and related data of the Guangdong Provincial Government in 2017, the article analyzes the financing difficulties and brain drain of small and medium-sized enterprises in the development process of the Pearl River Delta region by reading relevant materials and literature, and gives corresponding countermeasures. After the implementation of strategies, the corresponding problems can be solved to promote the economic development in China.

\section{ACKNOWLEDGMENT}

It took nearly a month to finally finish this paper. I encountered countless difficulties and obstacles in the process of writing the paper. I would like to thank Dr. Haowei, my thesis guide, for his selfless guidance and help. Take the trouble to help modify and improve the paper. I would like to express my most central gratitude to the teachers who have helped and guided me! Thanks to the scholars involved in this paper. This article cites the research literature of several scholars. Without the help and inspiration of the research results of all scholars, it would be difficult for me to finish the writing of this article.

Thanks to my colleagues and friends for giving me a lot of materials for your questions in the process of writing the paper, and also providing enthusiastic help in the process of writing and typesetting the paper.

\section{REFERENCES}

1. Li Yifu. Research on the influence of Guangdong SME clusters on economic development [J]. Times Economics and Trade, 2015(17): 104-106.

2. Yuan Youjun. The current situation and development thinking of small and medium enterprises in Guangdong [J]. Import and export manager, 2014(S1): 47-48.

3. Liu Ji. Research on the Development of Small and Medium-sized Enterprises in Guangdong and Government Behavior [D]. Shaanxi Normal University, 2013.

4. Feng Dechong. The dilemma and outlets of Shenzhen's small and medium-sized enterprises[J]. Special Zone Practice and Theory, 2013(04): $54-56+60$.

5. Wu Dequn. The transformation and upgrading of SMEs is imminent [N]. Shenzhen Special Zone News, 2012-08-24 (A06).
6. Gan Xiaoli, Li Yan. Problems and countermeasures in the development of foreign trade of small and medium-sized enterprises in Guangdong Province[J]. Entrepreneur World Semi-Monthly (Theory Edition), 2009(03): 240-241.

7. Kang Shuyao: Research on Financing Innovation of my country's Small and Medium-sized Enterprises-Taking the Pearl River Delta Region as an Example [J]. Business Accounting, 2018 (20): 73-75.

8. Yin Chengguo: Problems and countermeasures in the development of small and medium-sized enterprises in the Pearl River Delta [J]. Journal of Wuyi University (Social Science Edition), 2002 (03): $1-4+29$. 